\title{
Implementasi Machine Learning dalam Penentuan Rekomendasi Musik dengan Metode Content-Based Filtering
}

\author{
Aldy Istna Putra ${ }^{1}$, Reva Ragam Santika ${ }^{2}$. \\ ${ }^{1,2}$ Program Studi Teknik Informatika, Universitas Budi Luhur \\ email:1611510262@ student.budiluhur.ac.id ${ }^{1}$, reva.ragam@budiluhur.ac.id ${ }^{2}$.
}

(Received: 28 Mei 2020/ Accepted: 9 Juni 2020 / Published Online: 20 Juni 2020)

\begin{abstract}
Abstrak
Industri yang mengalami perkembangan yang signifikan adalah industri musik. Contoh perkembangannya adalah banyaknya platform aplikasi penyedia layanan musik online. Banyaknya data yang disimpan menyebabkan sulitnya menganalisa data yang ada, kehadiran Machine Learning dirasa mampu untuk menjawab tantangan tersebut. Meningkatkan user experience menjadi penting untuk memikat user agar menggunakan aplikasi yang dimiliki. Sistem rekomendasi menjadi salah satu cara untuk meningkatkannya. Penelitian ini bertujuan untuk membuat sistem yang dapat menyajikan rekomendasi musik sesuai dengan preferensi user sehingga tingkat kenyamanan user akan meningkat. Pengembangan sistem pada penelitian ini menggunakan metode Extreme Programming dengan beberapa tahapan, yaitu planning, design, coding, dan testing. Penelitian ini memanfaatkan Machine Learning dalam pencarian pola data serta metode Content-Based Filtering (CBF) dalam pencarian rekomendasinya. Sistem rekomendasi dengan metode $C B F$ mampu menghasilkan tingkat kemiripan lagu rata-rata hingga 0,6684 , serta nilai precision mencapai 0,125 dan 0,200 pada recall. Hasil Performance Testing dan System Testing yang diperoleh menyatakan bahwa sistem rekomendasi dapat berjalan baik dengan rata-rata response time mencapai 3,5 detik. Kesimpulan dari penelitian ini adalah sistem rekomendasi dengan metode CBF mampu menghasilkan rekomendasi yang sesuai dengan preferensi user, tetapi dengan data yang belum cukup banyak, diperlukan algoritma yang lebih efektif untuk data yang lebih besar.
\end{abstract}

Kata kunci: Content-Based Filtering, Machine Learning, Sistem Rekomendasi

\begin{abstract}
The industry that is experiencing significant development is the music industry. An example of its development is the many online music service providers of application platforms. The amount of data stored makes it difficult to analyze existing data, the presence of Machine Learning is felt to be able to answer these challenges. Improving user experience is important to attract users to use the applications they have. The recommendation system is one way to improve that. This research aims to create a system that can present music recommendations according to user preferences so that the user's comfort level will increase. The system developed in this research uses the Extreme Programming method with several stages, namely planning, design, coding, and testing. This research utilizes Machine Learning in searching for data patterns and Content-Based Filtering (CBF) methods in finding recommendations. The recommendation system with the CBF method can produce a song similarity level of up to 0.6684, as well as the value of precision reaching 0.125 and 0.200 at recall. The results of Performance Testing and System Testing obtained stated that the recommendation system can run well with an average response time 3.5 seconds. The conclusion of this research is that the recommendation system using the CBF method can produce recommendations that are in accordance with user preferences, but with not too much data. More effective algorithms are needed for larger data.
\end{abstract}

Keywords: Content-Based Filtering, Machine Learning, Recommendation System 


\section{PENDAHULUAN}

Musik merupakan salah satu hiburan yang cukup dibutuhkan bagi sebagian orang. Bagi sebagian orang mendengarkan musik dapat menenangkan hati dan jiwa, terutama jika kita mendengarkan musik yang sesuai dengan selera kita sendiri. Pada era teknologi ini, musik juga ikut mengalami perkembangan yang cukup signifikan, saat ini orang-orang dapat mendengarkan musik secara online melalui aplikasi-aplikasi music streaming yang tersedia pada smartphone. Mengambil hasil survey yang dilakukan Asosiasi Penyelenggara Jasa Internet Indonesia (APJII), mengatakan bahwa 35,5\% dari pengguna internet di Indonesia, atau sekitar 46,9 juta penduduk Indonesia mendengarkan secara online (Netti \& Irwansyah, 2018). Kecenderungan tersebut membuat beberapa perusahaan terutama yang bergerak di bidang digital konten untuk membuat aplikasi music streaming sendiri, sebagai contoh antara lain Spotify, Joox, LangitMusik, Pandora dan lain sebagainya. Ini membuat persaingan dalam memikat user sebanyak mungkin menjadi lebih ketat. Aplikasi-aplikasi tersebut berusaha membuat user interface serta user experience yang dapat menarik minat user baru untuk menggunakan aplikasi tersebut, serta membuat user yang telah menggunakannya merasakan kenyamanan dalam menggunakan aplikasi.

Banyaknya data dan informasi dari daftar musik atau lagu, user serta riwayat musik dari semua user dapat dimanfaatkan sebagai acuan dari sistem rekomendasi yang menjadi salah satu cara untuk meningkatkan user experience dari aplikasi. Dengan adanya data-data serta informasi tersebut dapat membuat sistem rekomendasi yang dibangun mampu menyediakan daftar rekomendasi yang sesuai dengan preference serta behavior bagi masingmasing user. Sehingga user tidak lagi kesulitan dalam mencari musik yang sesuai dengan selera masing-masing.

Data-data yang banyak tersebut jika dianalisa secara tradisional maka tidak akan efektif untuk mendapatkan informasi ataupun pola yang terkandung di dalamnya, metode yang cukup mampu untuk melakukan analisa data adalah machine learning, yaitu metode ekstraksi data yang merupakan gabungan dari ilmu kecerdasan buatan atau artificial intelligence dan ilmu komputer atau computer science (Müller \& Guido, 2016). Sistem rekomendasi merupakan salah satu cabang dari machine learning dengan jenis yang lebih spesifik. Tidak seperti model machine learning pada umumnya yang memprediksi suatu nilai berdasarkan input baru yang dihasilkan dari riwayat data sebelumnya, sistem rekomendasi lebih berfokus untuk menyediakan daftar produk, dalam hal ini musik yang dirasa akan disukai oleh user.

Machine learning adalah kumpulan algoritma pemrograman yang digunakan untuk mengoptimalkan kinerja komputer atau sistem berdasarkan data sampel yang ada sebelumnya (Alpaydın, 2020). Terdapat 7 langkah dalam machine learning, di antaranya yaitu mengumpulkan data, memepersiapkan data inputan, menganalisa data inputan, keterlibatan manusia, melatih algoritma, menguji algoritma dan menggunakannya (Harrington, 2012). Prinsip dasar machine learning yaitu memanfaatkan data untuk membuat model statistik, model tersebut pada umumnya digunakan sistem untuk melakukan prediksi masa depan berdasarkan data masa lalu yang diinputkan atau mempelajari pola yang terdapat di dalam data. Salah satu keunggulan utama dari machine learning adalah kemampuan modifikasi serta adaptasi dalam merespon perubahan data (Marsland, 2015). Machine learning dapat dimanfaatkan dalam banyak hal, sebagai contoh beberapa peneliti yang telah mengembangkan produk dengan memanfaatkan machine learning, seperti pada penelitian dengan tema prediksi pengambil mata kuliah. Tujuan penelitian tersebut adalah memprediksi apakah mata kuliah yang ada akan diambil oleh mahasiswa atau tidak. Hasil dari penelitian adalah prediksi jawaban 'Ya' atau 'Tidak' untuk mahasiswa dalam mengambil mata kuliah (Bachtiar, Syahputra, \& Wicaksono, 2019). Adapun penelitian dengan tema pendeteksi data spam SMS, pemanfaatan machine learning juga bisa diaplikasikan untuk memprediksi suatu 
SMS atau pesan sebagai spam atau bukan. Masalah dari penelitian ini adalah banyaknya SMS masuk yang tidak terdeteksi sebagai spam atau tidak, maka diperlukan seleksi tehadap SMS yang masuk tersebut. Pembuatan model machine learning dengan mengklasifikasikan data lama mampu memprediksi SMS yang masuk di masa depan sebagai spam ataupun bukan (Apandi \& Sugianto, 2018). Pada penelitian ini machine learning lebih digunakan sebagai sistem rekomendasi yang memprediksi apakah lagu akan didengarkan atau disukai oleh user. Tidak seperti pada umumnya hasil yang diberukan berupa true atau false, sistem rekomendasi ini menghasilkan daftar lagu yang diprediksi akan didengarkan oleh user.

Sistem rekomendasi diusulkan untuk menangani masalah informasi yang berlebihan. Ide dasarnya adalah untuk mewujudkan sistem dengan kemampuan untuk merekomendasikan kepada user tertentu suatu item yang paling relevan diantara opsi yang ada (Cunha, Soares, \& de Carvalho, 2018). Sistem rekomendasi akan memberikan rekomendasi suatu item yang sesuai untuk user tertentu dengan memprediksi kesukaan user pada item berdasarkan atribut terkait informasi tentang item, user dan hubungan antara item dan user. Rekomendasi dapat membantu meningkatkan kepuasan user secara keseluruhan terhadap aplikasi atau web. Sebagai contoh, seorang user yang berulang kali menerima rekomendasi yang relevan dari Amazon.com akan lebih puas dengan pengalaman yang diberikan serta cenderung akan menggunakan situs tersebut kembali. Ini akan meningkatkan loyalitas user dan lenih meningkatkan traffic pada aplikasi atau situs tertentu yang sudah mengadopsi sistem rekomendasi (Aggarwal, 2016). Dengan baiknya sistem rekomendasi yang ditawarkan, maka kemungkinan besar popularitas dan user experience aplikasi akan meningkat. Pada penelitian dengan tema pengembangan rekomendasi musik dengan metode User-Based Collaborative Filtering. Masalah penelitian adalah banyaknya informasi berlebihan yang menyebabkan sulitnya bagi user untuk menemukan informasi musik yang cepat dan sesuai kebutuhan (Budianto \& Hermawan, 2013). Perbedaan pada penelitian ini yaitu ada pada pemilihan metode yang digunakan dalam mencari rekomendasi. Penelitian ini menggunakan metode Content-Based Filtering, dimana metode ini tidak memerlukan data dari user lain sebagai acuan rekomendasi.

Content-based filtering memanfaatkan informasi yang terdapat di beberapa item atau data untuk dijadikan sebagai parameter yang menentukan rekomendasi yang sesuai untuk user. Content-based filtering menentukan rekomendasi berdasarkan jumlah nilai persamaan suatu item dengan item lainnya pada data. Metode ini akan memilih dan melakukan peringkat item berdasarkan kesamaan atribut item. Kelebihan dari metode ini adalah pengguna mendapatkan informasi tentang suatu item yang dianggap relevan untuk mereka, karena konten di setiap item dapat diketahui dari representasinya (Nastiti, 2019). Atribut serta deskripsi item berperan penting dalam proses filtering pada metode ini. Item dengan nilai kesamaan yang paling banyak terhadap kandidat item lain akan direkomendasikan kepada user sebagai rekomendasi (Thorat, Goudar, \& Barve, 2015). Dalam pembuatannya, contentbased filtering menggunakan perhitungan vecktor, TF-IDF, dan cosine similarity yang intinya dikonversikan dari data menjadi berbentuk vektor.

Pengembangan sistem rekomendasi bertujuan untuk memperkecil informasi yang berlebihan dengan menyeleksi informasi yang paling relevan dari data yang besar, serta memberikan daftar item yang sesuai dengan minat atau preferensi user. Sistem rekomendasi memiliki kemampuan untuk memprediksi preferensi user dengan menganalisis riwayat user atau riwayat user lain yang merupakan fitur utama dari sistem ini untuk menghasilkan suatu rekomendasi yang sesuai dengan preferensi dari masing-masing user. Fitur "People who bought also bought ..." pada Amazon adalah salah satu contoh dari industri atau perusahaan yang menggunakan sebuah sistem rekomendasi (Fathurrahman, Nurjanah, \& Rismala, 2017). 


\section{METODE}

Pengembangan perangkat lunak memiliki beberapa metode atau pendekatan, penelitian ini menggunakan metode Extreme Programming (XP) untuk membangun sistem rekomendasi. XP merupakan pengembangan perangkat lunak yang mencakup salah satu metode tangkas serta sederhana. Pada penelitian yang telah dilakukan Adelin dan Effendi (2017) penerapan XP dapat menghasilkan sistem dalam waktu yang lebih cepat dengan jumlah anggota yang lebih kecil (Adelin \& Effendi, 2017). Tujuan XP adalah membentuk tim secara khusus dengan ukuran tim yang lebih kecil hingga menengah, tidak perlu membentuk tim yang besar. Hal ini membuat XP sangat cocok untuk pengembangan sistem yang memerlukan adaptasi cepat pada perubahan-peruabahan requirement yang terjadi selama pengembangan sistem (Suryantara, 2017). Tahapan pada metode XP dapat dilihat pada gambar 1.

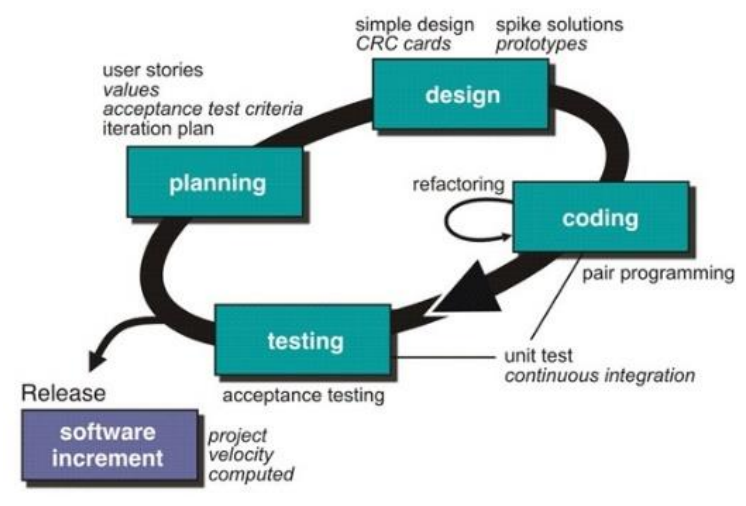

Gambar 1. Skema Extreme Programming

Pada proses planning dilakukan proses perencanaan sistem dengan menganalisa kebutuhan sistem serta identifikasi masalah yang dihadapi. Proses pengumpulan, pengolahan, serta analisis terhadap data yang akan digunakan sistem juga dilakukan pada tahapan ini. Data yang diperoleh untuk mendukung penelitian ini adalah data musik dari salah satu perusahaan nasional penyedia aplikasi musik online. Metode machine learning digunakan untuk mengolah dan menganalisis data.

Tahapan design ini dilakukan untuk merumuskan hasil pengumpulan dan analisa data terhadap sistem yang akan dibangun. Pada proses ini dilakukan penentuan algoritma yang akan digunakan untuk mengembangkan sistem, serta menentukan bagaimana sistem akan berjalan. Pada tahapan ini juga dilakukan pembentukan struktur sistem. Metode yang dipakai sistem untuk menentukan rekomendasi adalah content-based filtering, serta memanfaatkan cosine similarity.

Tahapan coding ini merupakan kegiatan implementasi struktur sistem yang sudah dibuat terhadap sistem yang akan dibangun. Pembuatan backend dan frontend dilakukan pada proses ini dengan menggunakan bahasa pemrograman. Proses machine learning dan proses rekomendasi yang berjalan pada backend menggunakan bahasa pemrograman Python dengan memanfaatkan library Pandas Dataframe dan Scikit-learn. Sedangkan interface yang dibuat sebagai contoh tampilan rekomendasi menggunakan bahasa pemrograman Android native atau Java.

Setelah tahapan coding selesai, dilakukan proses pengujian terhadap sistem untuk mengetahui sistem sudah berjalan baik atau tidak. Metode testing yang digunakan pada penelitian ini adalah Performance Testing dan System Testing. Pada tahapan ini juga dilakukan evaluasi terhadap hasil rekomendasi yang diberikan, evaluasi digunakan sebagai 
landasan penilaian terhadap kelayakan rekomendasi yang diberikan. Penelitian ini menggunakan metode evaluasi precision dan recall.

\section{HASIL DAN PEMBAHASAN \\ Hasil Penelitian}

Penelitian dilakukan dengan menggunakan data lagu sebanyak 11.737 serta 133.501 total riwayat lagu semua user. Kedua data tersebut digabungkan dengan memanfaatkan library Pandas Dataframe pada pemrograman python. Data hasil penggabungan tadi kemudian dipisahkan menjadi data train dan data test dengan total data test sebesar 0,2 dari total keseluruhan data. Fungsi data test tersebut nantinya digunakan untuk mengukur evaluasi sistem rekomendasi. Hasil analisis terhadap metode Content-Based Filtering menunjukkan bahwa metode ini sangat membutuhkan atribut lagu yang cukup detail untuk mendapatkan hasil rekomendasi yang baik. Penginputan detail dari masing-masing lagu secara benar dan jelas menjadi sangat vital perannya pada metode ini. Semakin baik detail maka pencarian rekomendasi juga akan menjadi lebih baik.

Metode pengujian yang dilakukan menggunakan metode Performance Testing dan System Testing. Performance testing digunakan untuk mengukur response time pada sistem ini. Dengan data yang dimiliki, response time rata-rata yang dihasilkan mencapai 3,5 detik setiap melakukan request, bukan hasil yang baik, namun juga tidak terlalu buruk. Selanjutnya system testing dilakukan untuk mengetahui apakah sistem sudah berjalan baik dan hasil yang diperoleh sesuai dengan yang diharapkan. Pengujian sistem dilakukan menggunakan Postman, hasil tampilan JSON dapat dilihat pada gambar-gambar di bawah ini.

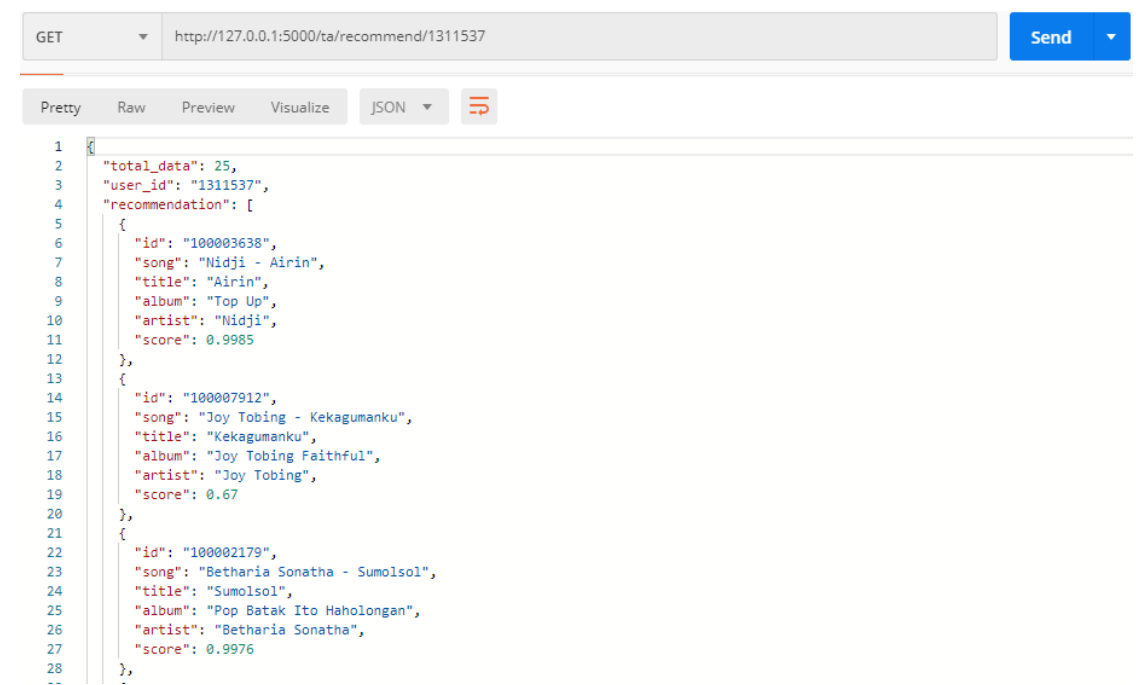

Gambar 2. Tampilan JSON Rekomendasi

JSON didapatkan dengan URL berdasarkan user_id yang diberikan. JSON yang dihasilkan nantinya bisa dimanfaatkan frontend sistem dengan mengambil data musik rekomendasi menggunakan key dari JSON tersebut. Contoh interface yang dikembangkan pada penelitian dapat dilihat pada gambar 3 dan 4 di bawah ini. 


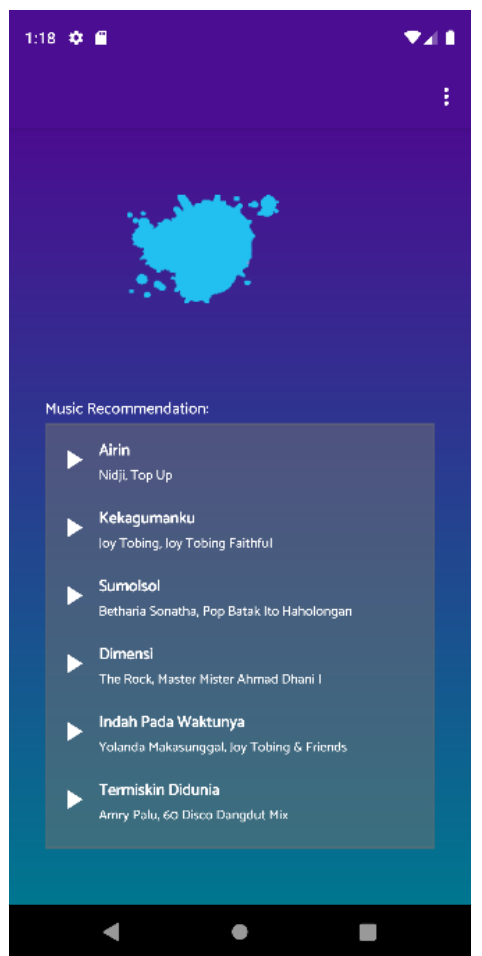

Gambar 3. Interface Rekomendasi User 1311537

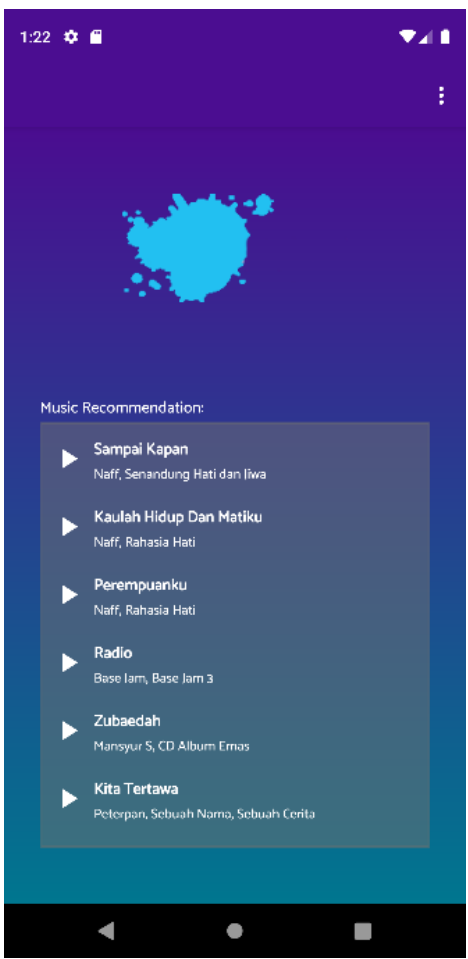

Gambar 4. Interface Rekomendasi User 1776649

Gambar 3-4 menunjukan daftar rekomendasi yang diberikan pada dua user berbeda satu dengan yang lainnya, ini menandakan hasil rekomendasi yang diberikan bergantung pada masing-masing user. Selanjutnya, pengujian pada penelitian ini dilakukan dengan sampel dua user berbeda untuk melihat apakah rekomendasi yang dihasilkan bisa berbeda antara user satu dengan user lainnya, serta melihat apakah rekomendasi yang dihasilkan sesuai dengan riwayat masing-masing user. Hasil pengujian tersebut dapat dilihat pada tabel-tabel di bawah ini.

Tabel 1. Top 10 Rekomendasi Musik pada User 1311537

\begin{tabular}{|c|c|c|}
\hline $\begin{array}{c}\text { Song } \\
\text { (Riwayat) }\end{array}$ & $\begin{array}{c}\text { Song } \\
\text { (Recommend) }\end{array}$ & Score \\
\hline Nidji - Jangan Lupakan & Nidji - Airin & 0.9985 \\
\hline Oktavia - Kau Mengasihiku & Joy Tobing - Kekagumanku & 0.6700 \\
\hline $\begin{array}{c}\text { Betharia Sonatha - Ito } \\
\text { Haholongan }\end{array}$ & Betharia Sonatha - Sumolsol & 0.9976 \\
\hline The Rock - Munajat Cinta & The Rock - Dimensi & 0.9966 \\
\hline $\begin{array}{c}\text { Christie - Tidak Dengan Tangan } \\
\text { Hampa }\end{array}$ & $\begin{array}{c}\text { Joy Tobing - Setia Sampai } \\
\text { Akhir }\end{array}$ & 0.5093 \\
\hline $\begin{array}{c}\text { Yolanda Makasunggal - Yesus } \\
\text { Kekuatan }\end{array}$ & $\begin{array}{c}\text { Yolanda Makasunggal - Indah } \\
\text { Pada Waktunya }\end{array}$ & 0.9790 \\
\hline Amry Palu - Cinta Sampai Disini & Amry Palu - Termiskin Didunia & 0.9881 \\
\hline Mbah Surip - Bangun Tidur & Mbah Surip - Tak Gendong & 0.9960 \\
\hline $\begin{array}{c}\text { Regina Pangkerego - Mujizat } \\
\text { Setiap Hari }\end{array}$ & Joy Tobing - Ku Selalu Aman & 0.4467 \\
\hline Dian Widya - Acuh Tak Acuh & Kristina - Jatuh Bangun & 0.4543 \\
\hline
\end{tabular}


Tabel 2. Top 10 Rekomendasi Musik Pada User 1776649

\begin{tabular}{ccc}
\hline $\begin{array}{c}\text { Song } \\
\text { (Riwayat) }\end{array}$ & $\begin{array}{c}\text { Song } \\
\text { (Recommend) }\end{array}$ & Score \\
\hline Naff - Bila Aku Pulang (live) & Naff - Sampai Kapan & 0.9795 \\
Naff - Bila Nanti Kau Milikku & Naff - Kaulah Hidup Dan Matiku & 0.8569 \\
Naff - A.n.g (live) & Naff - Perempuanku & 0.8538 \\
Base Jam - Bukan Pujangga & Base Jam - Radio & 0.9992 \\
Mansyur S - Jangan Pura Pura & Mansyur S - Zubaedah & 0.9945 \\
Peterpan - Semua Tentang & Peterpan - Kita Tertawa & 0.9959 \\
Kita & Edane - Cahaya & 0.4508 \\
Peterpan - Yang Terdalam & Naff - Bunga & 0.7755 \\
Naff - Kau Masih Kekasihku & & \\
(live) & Naff - Semestinya Kita & 0.7858 \\
Naff - Tak Seindah Cinta & & 0.7786 \\
Yang Semestinya (live) & Naff - Indah Tercipta & \\
Naff - Yang Tak Pernah Bisa & & \\
Mencintaimu (live) & &
\end{tabular}

Tabel 1-2 di atas menjelaskan bahwa setiap rekomendasi lagu yang diberikan itu diambil berdasarkan riwayat lagu, setiap riwayat lagu menghasilkan daftar rekomendasi lagu dengan score yang berbeda-beda bergantung pada nilai kesamaan antar lagu. Rekomendasi lagu yang ditampilkan merupakan rekomendasi dengan score tertinggi, namun juga lagu tersebut dicek apakah sudah pernah didengarkan oleh user atau tidak, jika sudah maka diambil rekomendasi dengan score dibawahnya. Hasil pengujian seperti yang disajikan pada tabel diatas mendapatkan nilai rata-rata persamaan lagu sebagai berikut: User 1311537 ratarata 0,8036 dan user 1776649 rata-rata 0,8470, maka rata-rata nilai persamaan yang didapat dari ketiga user tersebut adalah 0,8253, nilai rata-rata tersebut mengartikan bahwa algoritma untuk mencari persamaan antar lagu sudah cukup baik.

Evaluasi terhadap algoritma sistem rekomendasi ini juga dilakukan dengan menggunakan metode precision dan recall. Evaluasi ini menggunakan data test yang sebelumnya sudah dipisahkan sebanyak 0,2 dari keseluruhan data, lalu dibandingkan dengan hasil rekomendasi yang diberikan. Grafik evaluasi precision dan recall dapat dilihat pada gambar 5. Hasil tersebut menunjukan nilai precision atau nilai keakuratan antara lagu yang direkomendasikan dengan dengan data test, nilai precision menghitung berapa banyak data lagu yang didengarkan user dari keseluruhan rekomendasi lagu yang diberikan. Data test tersebut merupakan data lagu yang memang didengarkan oleh user. Nilai precision pada evaluasi ini mencapai angka 0,125. Sedangkan nilai recall atau nilai keberhasilan model dalam menemukan kembali sebuah informasi. Nilai recall menghitung berapa banyak lagu yang direkomendasikan dibandingkan keseluruhan lagu yang sebenarnya didengarkan oleh user. Nilai recall yang diperoleh mencapai angka 0,200. 


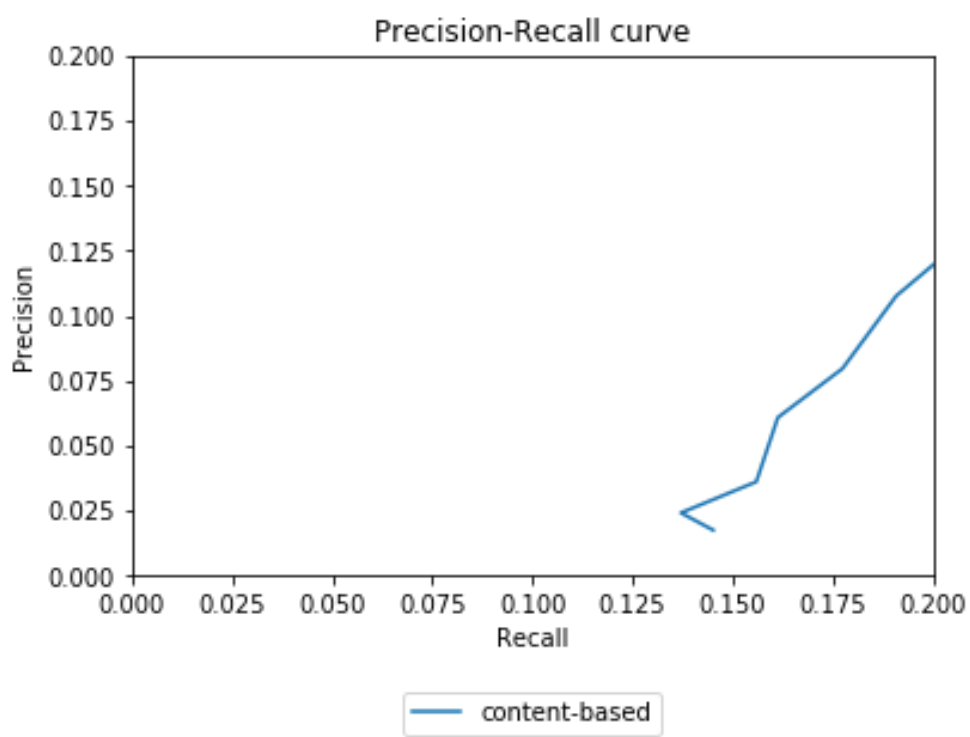

Gambar 5. Grafik Evaluasi Precision dan Recall

\section{Pembahasan}

Berdasarkan hasil pengujian terhadap tiga user berbeda sistem rekomendasi musik dapat menampilkan daftar rekomendasi musik yang berbeda antara user bergantung pada riwayat user tersebut, sistem rekomendasi akan membandingkan satu lagu dari riwayat user dengan daftar lagu yang ada pada database, lalu dihitung persamaannya berdasarkan atribut yang dimiliki oleh lagu-lagu tersebut, nilai persamaan tertinggi akan diambil sebagai rekomendasi, namun sebelumnya dilakukan pengecekan apakah lagu yang direkomendasikan sudah ada pada riwayat user atau belum, jika ada maka diambil lagu dengan nilai tertinggi setelahnya. Riwayat lagu yang digunakan adalah 10 lagu dengan total pendengaran terbanyak, dari kesepuluh lagu tersebut maka dapat diambil 10 lagu rekomendasi atau bisa disebut Top 10 Recommendation.

Hasil temuan yang diperoleh berdasarkan analisa adalah sistem rekomendasi dapat berjalan dengan data yang belum begitu besar, dengan data yang digunakan saat penelitian yaitu sekitar 11.000 data lagu, sistem dapat berjalan namun dengan performa yang belum bisa dibilang baik. Hasil rekomendasi yang diberikan sudah cukup sesuai, dengan rata-rata similarity score per user mencapai 0,8 , yang menandakan bahwa lagu yang direkomendasikan sudah sesuai dengan preferensi masing-masing user. Perbandingan analisis dengan penelitian sebelumnya yang menggunakan metode Collaborative Filtering yaitu metode tersebut memerlukan data rating user terhadap lagu, penilaian dari user atau user lain sangat berpengaruh terhadap penentuan rekomendasi. Metode evaluasi pada penelitian tersebut menggunakan MAE (Mean Absolute Error) didapatkan data yaitu 0,6713 dengan skala 0 - 1. Pada penelitian ini, pencarian rekomendasi tidak terpengaruh terhadap penilaian user terhadap lagu, rekomendasi yang diberikan berpengaruh pada nilai atribut dari masingmasing lagu. Pada penelitian ini memanfaatkan atribut detail dari lagu, kedepannya dapat dikembangkan dengan mencari atribut berdasarkan lirik lagu ataupun dengan mengekstrak nada dari tiap lagu dan mencari kesamaan dengan lagu lainnya. Evaluasi yang dilakukan pada penelitian ini yang menggunakan metode precision dan recall mendapatkan nilai 0,125 pada precision dan 0,2 pada recall.

Berdasarkan aspek pengujian serta evaluasi sistem rekomendasi yang dilakukan menunjukan bahwa metode ini layak digunakan sebagai metode dalam penentuan rekomendasi musik. Sebagai produk hasil pengembangan, sistem rekomendasi ini memiliki kelebihan serta kekurangan. Kelebihan sistem rekomendasi ini adalah sistem dapat 
menyajikan daftar rekomendasi musik yang sesuai dengan riwayat lagu masing-masing user, serta daftar rekomendasi yang diberikan berbeda antara user satu dengan yang lain. Kelemahan dari sistem ini adalah jika menggunakan dataset yang lebih besar maka memerlukan requirement hardware yang lebih mumpuni, pencarian nilai persamaan lagu dengan dataset yang banyak akan menyebabkan lambatnya sistem berjalan, karena akan memakan memori yang cukup banyak. Sistem rekomendasi ini didesain untuk sistem yang masih memiliki data lagu yang belum cukup banyak, kedepannya bisa dikembangkan algoritma yang sesuai jika memiliki dataset yang besar.

\section{SIMPULAN}

Berdasarkan hasil temuan kami mengenai sistem rekomendasi ini adalah metode content-based filtering dengan cosine similarity telah berhasil menampilkan daftar rekomendasi musik. Atribut dari tiap lagu harus dimasukkan sedetail mungkin untuk menghasilkan nilai persamaan yang baik. Hasil evaluasi yang dilakukan mendapatkan nilai recall antara 0,150 sampai 0,200 , serta precision mencapai nilai antara 0,015 sampai dengan 0,125 , sehingga rekomendasi yang dihasilkan sesuai dengan preferensi user. Selain itu, sistem ini dapat berjalan baik pada dataset yang belum begitu banyak, namun akan bermasalah jika menggunakan dataset yang lebih besar, terutama pada performance dari sistem ini, diperlukan algoritma yang lebih efisien untuk sistem dengan jumlah data yang banyak.

\section{REFERENSI}

Adelin, \& Effendi, H. (2017). Aplikasi Audit Mutu Akademik Internal dengan Pendekatan Extreme Programming. Jurnal TI Atma Luhur, 4(1), 13-24.

Aggarwal, C. C. (2016). Recommender Systems: The Textbook. Springer. Basel. Switzerland. Alpaydın, E. (2020). Introduction to Machine Learning. $4^{\text {th }}$, Massachusetts: MIT Press.

Apandi, T. H., \& Sugianto, C. A. (2018). Analisis Komparasi Machine Learning pada Data Spam SMS. Jurnal TEDC, 12(1), 58-62.

Bachtiar, F. A., Syahputra, I. K., \& Wicaksono, S. A. (2019). Perbandingan Algoritme Machine Learning untuk Memprediksi Pengambil Matakuliah. Jurnal Teknologi Informasi Dan Ilmu Komputer, 6(5), 543-548.

Budianto, T., \& Hermawan, G. (2013). Rancang Bangun Music Recommender System dengan Metode User-Based Collaborative. Jurnal Ilmiah Komputer Dan Informatika (KOMPUTA), 2(2), 1-10.

Cunha, T., Soares, C., \& de Carvalho, A. C. P. L. F. (2018). Metalearning and Recommender Systems: A literature Review and Empirical Study on the Algorithm Selection Problem for Collaborative Filtering. Information Sciences, 423(1), 128-144.

Fathurrahman, M. I., Nurjanah, D., \& Rismala, R. (2017). Sistem Rekomendasi pada Buku dengan Menggunakan Metode Trust-Aware Recommendation Recommendation System for Book by using Trust-Aware Recommendation Method. E-Proceeding of Engineering, 4(3), 4966-4977.

Harrington, P. (2012). Machine Learning in Action. New York: Manning..

Marsland, S. (2015). Machine Learning: An Algorithmic Perspective. USA: CRC Press.

Müller, A. C., \& Guido, S. (2016). Introduction to ML with Python: A Guide for Data Scientists. California: O'Reilly Media, Inc.

Nastiti, P. (2019). Penerapan Metode Content Based Filtering dalam Implementasi Sistem Rekomendasi Tanaman Pangan. Teknika, 8(1), 1-10.

Netti, S. Y. M., \& Irwansyah, I. (2018). Spotify: Aplikasi Music Streaming untuk Generasi Milenial. Jurnal Komunikasi, 10(1), 1-16.

Suryantara, I. G. N. (2017). Merancang Aplikasi dengan Metodologi Extreme Programmings. 
Jakarta: PT Elex Media Komputindo

Thorat, P. B., Goudar, R. M., \& Barve, S. S. (2015). Survey on Collaborative Filtering, Content-based Filtering and Hybrid Recommendation System. International Journal of Computer Applications, 110(4), 31-36. 